\title{
THE EFFECT OF USING VIDEO LISTEN-READ-DISCUSS STRATEGY TOWARD STUDENT'S READING COMPREHENSION OF RECOUNT TEXT AT THE SECOND GRADE OF SMP MUHAMMADIYAH RAMBAH
}

\author{
EviKasyulita, RiviAntoni, Nursyafitri \\ eviyulita23@yahoo.com,antoni.rivi888@gmail.com, \\ nursyafitri071@gmail.com
}

English Study Program Faculty of Teacher Training and Education University of Pasir Pengaraian

\begin{abstract}
The purpose of this research were to find out students reading comprehension of recount text taught through LRD strategy and taught without using LRD strategy. And to find out whether there was an effect of using LRD strategy toward students reading comprehension of recount text at the second grade of SMP MuhammadiyahRambah. This research was an experimental research, precisely a quasi experimental research. The instrument of this research was multiple choices test of reading comprehension. The participants were students at second grade of SMP Muhammadiyah Rambah. The researcher findings showed that the improvement from the score of t-test. The total score of t-test was 3.451. Based on p-value was $0.003<0.05$. Therefore, it could be concluded that there was an effect of using LRD strategy toward students reading comprehension of recount text at the second grade students of SMP Muhammadiyah Rambah.
\end{abstract}

Keywords: Reading, Recount Text, LRD Strategy

\section{INTRODUCTION}

\section{Background of The problem}

Study English is a very important. There are four skill that should be taught to the students at school, they are listening, speaking, reading, and writing. They cannot be separated from other aspects of language such as of grammar and vocabulary. One of skill that cannot be neglected is reading skill. Reading skill becomes very important in the education field for it is very essential in 
learning English. Reading is most emphasized in English teaching and learning process.

Reading skill should be thought earlier to the children (Tessero: 2003). Reading habits can increase the students' achievement. The purpose of reading in many languages is to inform ourselves about something we are interested, or to challenge certain our methods.

Based on the researcher's observation on 23 January 2020 at SMP Muhammadiyah Rambah, student still had problems in reading comprehension, especially on recount text. The first students have problem in identifying the generic structure of the recount text. They are not able to identify the important aspect in recount text such as orientation, events and reorientation. students also had problems in determine the events of text, difficult to arrange the events of text because of lack vocabulary. They are confuse about how to arrange the generic structure of the recount text.

The second was some students also had problems in getting information of recount text, student do not compare their background knowledge with what text is if is done by students, it would been easy to get information of recount text. When student are told to make recount text, they try to translate word by word.

The third problem was some of the students had lack of vocabularies, we know that vocabularies are very important to be used in reading text, because the purpose of reading is to get information. Students can find the information of a text if they have understanding of vocabulary. The vocabulary make students easy to understand the information in recount text.

Therefore, the writer tried to apply an alternative technique to solve these problems that is used to make students be easier in learning a text, especially recount text. The alternative that have chosen was known "Listen-ReadDiscuss (LRD) strategy. According to Richardson (1999: 10) LRD is a comprehension strategy that builds students' prior knowledge before they read a text, during reading and after reading by listening the teacher's short lecture, reading a text selection, and discussing. This strategy can help the students

\section{Purpose of the Research}

In this research the researcher tries to find out whether is there any significant the effect of using ListenRead-Discuss strategy toward student reading comprehension of recount text at the second grade of SMP Muhammadiyah Rambah.

\section{REVIEV OF RELATED LITERATURE}

\section{Reading}

Reading is one of four skill in English that the students should acquire. Nunan (2003:8) states that reading is a process of readers combining 
information from the text and their own background to build meaning. its means that reader should combine their knowledge and what the information they read.

According to Patel and Jain (2007; 113) state that reading is an important activity in life with which one can update his/her knowledge. It means that reading has usefulness for providing more understanding in subject learning and it has important part in life which can update her/his knowledge.

In addition utami (2014:01), reading is one of important skills in a second language acquisition, particularly in English as a foreign language. It shows that students reading skill is needed to find the information of the text because reading is an important way for student's reading process in finding the information of the text. The using of reading skill is very important in finding messages from written text.

According to Anderson, Hiebert, scott, and Wilkinson (1985,p.7) reading is the process of constructing meaning from written texts. It is a complex skill requiring the coordination of a number of interrelated sources of information. Its means that reading is a complicated process of extracting meaning from written text sand in order to be able to read information sources are needed.

In addition, reading is an activity to find information. It is an active process that needed by student to get information. Reading is an activity to understand the meaning of written text. Its means that reading is a process of perceiving a written text in order to understand its contents and information.

Base on the definition above, it can be conclude that reading is a way of finding information. It is a facilitator that has important contribution in learning process. As one of important skill, mastering reading has some rules that have to be use by reader such as the combination of information. Its means that students must use reading to get the information effectively. And reading is an activity process to create the meaning from the text.

\section{Reading Comprehension}

According to Kustaryo (1988) reading comprehension means understand what has been read, and it is an active thinking process that depends not only on comprehension skill but also the student experience and prior knowledge comprehension involves understanding of vocabulary seeing the relationship among words and concept organizing ideas, recognizing ideas, recognizing author's making judgment and evaluating. So from this point of few, it can be said that the reading comprehension is very important for the student if the student does not understand what they read they cannot catch the meaning of the text.

Comprehension is the essence of reading and the active process of constructing meaning from text (Durkin, 1993). Reading comprehension is a complex interaction among 
automatic and strategic cognitive processes that enables the reader to create a mental representation of the text (van den Broek\&Espin, 2012). Comprehension depends not only on characteristics of the reader, such as prior knowledge and working memory, but also on language processes, such as basic reading skills, decoding, vocabulary, sensitivity to text structure, inferencing, and motivation. Comprehension also requires effective use of strategic processes, such as metacognition and comprehension monitoring. As readers mature in their comprehension skills, they are able to progress efficiently from the stage of learning to read to the ultimate goal of reading to learn (Yovanoff, Duesbery, Alonzo, \& Tindal, 2005).

From the explanation above, conclude that reading comprehension is a understanding process of the text by constructing meaning and combining knowledge whit written text. When the reader read a text, they have make the connection with the text. It means that student have to understand what they read to get the meaning and information from the text.

\section{Listen-Read-Discus Strategy}

According to Manzo and Casale (1985) stated that LRD strategy is a comprehension strategy that builds students' prior knowledge before they read a text.Listen - read - discuss strategy is a strategy helps students understand text. The teacher gives a short teach to the students. Then the students read the text that the teacher spoke about. After reading, the students discuss the information they read and the lecture of the teacher give. This strategy also helps the students use their prior knowledge

In addition Jennifer Hamilton's statement is support by Tarek Elabsy (2013) stated that for the struggling students, who have difficulty reading proficiency on their own, benefit from this activity because they activate their prior knowledge through listening to the teacher's introduction of the topic. the teacher asks the students to listen to his or her presentation, to read, and to discuss what they read with each other to deepen their understanding. Therefore, to ensure student interest, the teacher should select topics of which students do not have prior knowledge.

Richardson (1999) cited from Ibrahim (2017) Listen-Read-Discuss is a strategy of comprehension that construct students' prior knowledge before they read a text, during reading and after reading by listening the teacher's short lecture, reading a text selection, and discussing.

This strategy may help studentsunite between the author's words and theirown, thus take affect in their comprehension tolearning and remembering about what theyread. Moreover Purwanti (2017) said that using Listen-Read-Discussstrategy found that the students enjoyed morein learning reading and comprehend the texteasily. It can be stated that through LRDstrategy students enjoyed more and become motivated to learn English.
According

to 
Discuss (LRD) is heuristic meets these requirements for teachers and students. It offers simple lesson design that can be tried almost immediately and provides several elaborations on the basic design that can be phased in as necessary and appropriate.mcKenna (2015:211) Manzo and Casale introduced a technique for improving comprehension that assumes little or no background knowledge for a nonfiction reading selection. Rather than creating a foundation of knowledge that will be useful for co prehending the additional knowledge presented in the selection, the teacher actually covers the content of the selection.

According to McKenna (2002: 60), LRD strategy has been shown to increase students' science inquiry strategies, and overall text comprehension compared to control classrooms with separate scienceand literacy curricula and/or strategy instruction on reading alone. Particular interest in the LRD strategy research is the pivotal role that motivation, in all of its instantiations (interest and achievement motivation), plays in learning both science and literacy.

According to Manzo and Rasinski (1985) states that there are three advantages of using this strategy; First, In the fact that it is a powerful tool for engaging struggling readers, especially second language learners. Because the content of the text is cover orally at the beginning, the learners who are unable to read the text on their own, are able to gain at least a surface understanding about the reading. Second, for students who lack prior knowledge about the content gain it during the listening stage, which will allow them to more easily comprehend the text during the reading stage. Third, this strategy gives the effectiveness in teaching and learning reading.

This opinion is also support by TarekhElabsy, he state that this strategy have the advantages in each steps; first is "listen" it provides students with essential background information and text structure that makes the text more accessible to multi-level readers. With this preview, students are more motivated to read and can focus on the meaning of the text, rather than wrestle with completely new words and concepts. This portion also models the reading process by demonstrating how the teacher interpret the text, decided on important ideas, used the text structure and summarized content. The second is "read" it provides focus reading time. If done in partners, it provides more support and a chance to discuss for struggling readers. And the last is "discuss" it provides students a chance to critically discuss the text, state opinions and use the text to support what they say. Students should gradually assume the responsibility for the discussion. (TarekhElabsy; 1985).

\section{RESEARCH METHODOLOGY}

This research was designed as a quasi experimental research, because the researcher wants to do an experiment research about the effect of the use of Listen-Read-Discuss strategy in teaching English toward students' reading comprehension on narrative text 
to the second grade $\mathrm{f}$ SMP Muhammadiyah Rambah.

\section{Data}

In this research, the researcher use pre-test and post-test to collect the data. The researcher give Listen-ReadDiscuss (LRD) strategy as the treatment in experimental class and control class was not given by researcher. This process was use to examine about the significant effect between treatment class and control class.

In analysis the data the researcher analyzed and counted the score between pre-test and post-test of experimental and control class using the descriptive data analysis. In analyzing the result of the pre test and post test of this research, hthe researcher used the following formula :

$$
\mathbf{P}=\frac{\mathbf{F}}{\mathrm{N}} \times 100 \%
$$

Notes :

$\mathrm{P}=$ Total Score

$\mathrm{F}=$ Number correct answer

$\mathrm{N}=$ Number of test items

The researcher calculate deviation between pre-test and post-test of experimental and control group. To analyze the data, the researcher used the statistical test and the researcher used the SPSS application to calculate the result of the test.

To analyze the data about the significant difference before and after of student reading comprehension between those that was taught by using ListenRead-Discuss strategy, the data was analyzed statistically. The independent sample t-test and pair sample t-test was use througt using SPSS 17.0 version.

To analyzing the data, the researcher used T-test by sundayana (2010: 146). It use to examine Significant effect between using LRD strategy and without using LRD strategy in posttest. To measure, the researcher used independent sample $\mathrm{T}$-test provision sig $\leq 0.05=\mathrm{Ho}$ is rejected and $\mathrm{Ha}$ is accepted and if $\operatorname{sig} \geq 0.05=\mathrm{Ho}$ is accepted and $\mathrm{Ha}$ is rejected or t-value > $\mathrm{t}$-table $=\mathrm{Ho}$ was rejected and Ha was accepted. But, if $\mathrm{t}$-value $<\mathrm{t}$-table $=\mathrm{Ho}$ was accepted and Ha was rejected.

\section{FINDING AND DISCUSSION}

In this section, the researcher analyzed the data which had been collected and then described the result of the research . The calculated by using SPSS to measure the result of post-test score both two classes show that t-value both of two classes was 3.451. and pvalue both of two classes 0.003 , with sig. 5\% (0.05). It mean Ha was accepted and Ho was Rejected. To overall both of classes in experimental and control the students now were able to identify the generic structure of recount text and the students could identify the information of the recount text. So, using Listen-Read-Discuss strategy gave an effect to the students reading comprehension to the second grade students at SMP Muhammadiyah Rambah. The finding of this research was supported by some experts statements such as : Manzo (2005)“LRD (Listen Read Discuss) strategy is one teaching strategy for the 
teacher and learning strategy for the students more active in comprehending material. It means that LRD (Listen Read Discuss) strategy can help the students to comprehend about text and students can discuss make students exchange ideas to their friends.

This result was supported by Manzo and Rasinski (1985) three were some advantages of using LRD strategy; (1), In the fact that it is a powerful tool for engaging struggling readers, especially second language learners. Because the content of the text is cover orally at the beginning, the learners who are unable to read the text on their own, are able to gain at least a surface understanding about the reading. (2), for students who lack prior knowledge about the content gain it during the listening stage, which will allow them to more easily comprehend the text during the reading stage. (3), this strategy gives the effectiveness in teaching and learning reading.

In addition, (Tarekh

Elabsy,1985) he state that this strategy have the advantages in each steps; first is "listen" it provides students with essential background information and text structure that makes the text more accessible to multi-level readers. With this preview, students are more motivated to read and can focus on the meaning of the text, rather than wrestle with completely new words and concepts. This portion also models the reading process by demonstrating how the teacher interpret the text, decided on important ideas, used the text structure and summarized content. The second is "read" it provides focus reading time. If done in partners, it provides more support and a chance to discuss for struggling readers. And the last is "discuss" it provides students a chance to critically discuss the text, state opinions and use the text to support what they say. Students should gradually assume the responsibility for the discussion.

\section{CONCLUSION}

After conducting the research and analyzing the data, the researcher concluded that there was a significant effect of using LRD strategy on students reading comprehension of recount text. It caused after looking at the frequency distribution of students pre-test in the experimental class dominant score obtained is categorized is very poor and the frequency distribution of students post-test has been increased fair. And result of the data calculation on previous chapter where null hypothesis (Ho) was rejected and alternative hypothesis (Ha) was accepted with sig. in independent sample t-test was 0.003 smaller than $\alpha=$ 0.05. it means that, Listen-Read-Discuss strategy could give a significant effect on students reding recount text.

Based on the result of the data analysis, the researcher conclude that there was any significant effect of using Listen-Read-Discuss strategy on students reading comprehension of recount text at the second grade of SMP MuhammadiyahRambah. So that, Listen-Read-Discuss strategy was improved the students reading comprehension of recount text at the 
second grade of SMP Muhammadiyah Rambah. Then, the students now were able to identify the generic structure of recount text and the students could identify the information of the recount text. So, this strategy has an effect on student reading learning where students grade have been high.

\section{REFERENCE}

Al-Jarrah, H., \& Ismail, N. S. B. (2018).Reading Comprehension Difficulties Among EFL Learners in Higher Learning Institutions. International Journal of English Linguistics, 8(7), 32-41.

Arifin, E. (2019). A Comparative Study of Listen-Read-Discuss and Think-Pair-Share Strategies on Students'Reading Achievement (Doctoral dissertation, Universitas Negeri Makassar).

Atasyah, N. F. The effect of using listenread-discuss (lrd) strategy on students' reading comprehension of narrative text (A Quasiexperimental Research at Tenth Grade of SMAN 04 Pondok Ranji, Kota Tangerang Selatan in Academic Year 2019/2020) (Bachelor's thesis, (Jakarta: FITK UIN Syarif Hidayatullah Jakarta)).

Dwiono, R. (2017). Listen-ReadDiscuss in Teaching and Learning Reading Comprehension: A Case Study of Private Senior High School in Lampung. In Proceeding of International Conference on Art, Language, and Culture (pp. 433-442).
Elita, D., \& Radjab, D. (2013).Improving

Students'Reading Comprehension of Recount Text Through Two Stay Two Stray (tsts) Technique at Grade viii 1 of SMP N 2 Tilatang Tamang agam.English Language Teaching (ELT), 1(2).

Hanapi, H.The Listen, Lead, Discuss (lrd) Strategy in Improving the Student Reading Skill of Recount Text at smp $n 2$ buru.

Ibrahim, R. (2017).The Use of Listen Read Discuss Strategy and Reading Motivation Toward the Students' Reading Comprehension. ELT-Lectura , 4 (2).

Jayanti, F. G. (2016). Reading Difficulties: Comparison on Students' and

Teachers'Perception. Proceedings of ISELT FBS Universitas Negeri Padang, 4(1), 296-301.

Khairunnisa, P. (2018). The Implementation of lrd (listen read discuss) Strategy on The Students' Ability in Mastering Reading Comprehension at MAS YPRaudhatul Akmal Batang Kuis(Doctoral Disertation, Universitas Islam Negeri Sumatera Utara).

Ningtyas, W. A. (2015). Improving Reading Comprehension of The Grade viii Students at SMP N 9 Magelang Through Directed Reading Thinking Activity (drta) in the academic year of 2014/2015 (Doctoral Dissertation, Yogyakarta state University). 